\title{
BITRIBUTAÇÃO - IMPOSTO DE CONSUMO E TAXA DE FISCALIZAÇÃO
}

- Não se confunde com o impôsto de consumo, da competência da União, a aposição do "sêlo de garantia", que o Estado cobra, no vasilhame das águas procedentes de fontes minerais, o qual constitui, a rigor, uma taxa de fiscalização. tação.

- Não constando que a Uniäo cobre igual taxa, não há bitribur

TRIBUNAL DE APELAÇÃo DE MINAS GERAIS

Olímpio A. Bittencourt versus Fazenda Pública Estadual

Agravo n.0 1.183 - Relator : Sr. Desembargador

\section{Autran Dourado}

\section{ACÓRDÃo}

Vistos, relatados e discutidos êstes autos de agravo da comarca de Além Paraíba, entre partes : Olímpio A. Bittencourt, agravante, e a Fazenda Pública estadual, agravado. 
Acordam em Turma da Segunda Câmara Civil do Tribunal de Apelação do Estado de Minas Gerais, adotando o relatório retro como parte integrante dêste, conhecer do recurso com o fundamento invocado, mas para negar-lhe provimento, mantendo, assim. a decisão recorrida que procede por seus próprios fundamentos pagas as custas pelo agravante.

Assim decidem, porque o presente agravo é cantra a decisão de fls., em a qual o Dr. Juiz de Direito, não encontrando inconstitucionalidade alguma, por bitributação, na cobrança do impôsto de sêlo de garantia, constante da tabela 6, n. $^{\circ} 122$, da Lei n. $0^{\circ} 67$, de 1938 , que, por não ter sido pago em tempo, é agora cobrado por esta ação do executado, ora agravante, pela importância a que se refere a inicial julgou a ação procedente e subsistente a penhora, desprezando os embargos de fls.

E muito bem fêz em assim julgar o Dr. Juiz a quo, de vez que, de fato, não existe a bitributação pretendida, na disposição da tabela 6 , n. ${ }^{\circ} 122$, da Lei $n .^{\circ} 67$, citada, porque, em verdade, em nada êle se parece com o impôsto de consumo que à União compete taxar privativamente, nos têrmos da letra $b$ do n. 1 do art. 20 da Constituição Federal de 10 de novembro de 1937, que por fôrça dêste inciso cobra.

$\mathrm{E}$ isso porque o sêlo a que se referem o-número_e_tabela_citados constitui, como o próprio nome diz, um "sêlo de garantia" de que a água que se encontra no vasilhame é pura e que saiu das fontes minerais do Estado, sem substância alguma que the tire as propriedades naturais.

E' uma taxa de fiscalização, para evitar a alteração do produto, em favor dos que dêle usam.

São impostos diferentes e para fins diferentes, não existindo, portanto, bitributação alguma na cobrança que se faz neste executivo, porque, como se sabe, a bitributação nada mais é do que a cobrança do mesmo impôsto e para o mesmo fim, por entidades diferentes, e que não é o caso đêstes autos.

Acresce que, como se tem dito, e nunca é demais repetir, não basta invocar o espirito da Constituição para se declarar a inconstitucionalidade de uma lei; é necessário que a violação constitucional seja clara e evidente, o que, como se disse, não aparece no caso em tela.

Mas, admitindo-se, apenas para esclarecimento, que, em se tratando de uma taxa de fiscalização, a cobrança pertença à União, em face do art. 44 do Código de Minas, mesmo assim não existirá a bitributação, pois não consta que a União cobre alguma taxa por igual motivo, e enquanto isso não fizer, ao Estado não se pode negar o direito de fazê-lo, em face do art. 18 da Constituição vigente, que permite aos Estados, independente de autorização, legislem no caso de haver lei federal sôbre a matéria, para suprir-lhe as deficiências ou atender às peculiaridades locais, desde que não dispensem ou diminuam as exigências da lei federal, ou, em não havendo lei federal e até que esta as regule, sôbre os seguintes assuntos: "assistência pública, obras de higiene popular, casas de saúde, clínicas, estações de clima e fontēs medicinais".

Eis por que, como se disse, conhecem do recurso, mas para manter a decisão recorrida.

Belo Horizonte, 29 de novembro de 1943. - Batista de Oliveira, presidente: Autran Dourado, relator; Amílcar de Castro, vogal, pela conclusão. 